\title{
Could We Reduce the Prevalence of Inflammation among Patients with Chronic Kidney Disease?
}

\author{
See Ateş et al., pp c190-c197
}

\section{Olimpia Ortega}

Nephrology Service, Hospital Severo Ochoa, Leganés. Madrid, Spain

Chronic renal failure is associated with a significantly increased risk for cardio-vascular (CV) disease and for $\mathrm{CV}$-related mortality [1]. Among the non-traditional risk factors for the development of $\mathrm{CV}$ disease in patients with chronic kidney disease (CKD), chronic inflammation deserves special attention. The prevalence of inflammation among patients with CKD is high and several studies have shown that inflammation is a powerful predictor of mortality in dialysis patients, mainly due to cardiovascular events [2-4].

An activated inflammatory response is frequently detected also in patients with CKD prior to initiation of dialysis [5-7]. The mechanisms underlying an activated acute-phase response in pre-dialysis patients are not yet fully understood. A decreased renal clearance of pro-inflammatory cytokines or C-reactive protein (CRP) has been suggested by some authors [7], as they found a negative correlation between serum CRP and creatinine clearance in patients with a wide range of renal insufficiency.

In this issue of Nephron Clinical Practice, Ates et al. [8] analyze the prevalence of elevated serum CRP in patients with different stages of chronic renal insufficiency. They have found a strong negative correlation between CRP levels and creatinine clearance. The prevalence of elevated serum CRP was increased in the subgroup of patients with more advanced renal failure. However, as detected in previous studies [5-7], CRP levels were not normally distributed, suggesting the presence of a mixed population of different subgroups of patients: patients with high and patients with normal CRP values despite a similar creatinine clearance. The results suggest that reduced renal function by itself could not be fully responsible of the inflammatory response. It seems that other factors, frequently associated with renal failure and which can worsen with the worsening of renal function, may contribute to activate the inflammatory response.

Ates et al. [8] also analyzed echocardiographic data in their patients. They found a strong direct correlation between CRP levels and left-ventricular mass index (LVMi) and between CRP and fractional shortening, suggesting an association between inflammation and left-ventricular hypertrophy or dysfunction. The authors conclude that serum CRP is an independent factor affecting CV disease and that inflammation may play a key role in the pathogenesis of left-ventricular abnormalities.

Nevertheless, the interpretation of these interesting results could be different. Our group has recently found a strong association between CRP and N-terminal pro-Btype natriuretic peptide (N-BNP) values in patients with advanced renal failure [9]. B-type natriuretic peptide (BNP) is a cardiac neurohormone specifically secreted

\section{KARGER \\ Fax +41613061234 E-Mail karger@karger.ch} www.karger.com
(C) 2005 S. Karger AG, Basel $1660-2110 / 05 / 1014-0198 \$ 22.00 / 0$

Accessible online at: www.karger.com/nec
Dr. Olimpia Ortega

Servicio de Nefrologia, del Hospital Severo Ochoa

Avda. Orellana s/n

ES-28911 Leganés, Madrid (Spain)

Tel. +34914818 00, Fax +34916931 259, E-Mail oortega.hsvo@salnd.madrid.org 
from cardiac ventricles in response to myocardial stretch as a consequence of pressure or volume overload [10]. Even in patients with chronic renal failure, BNP has emerged as a reliable marker of left-ventricular volume or pressure overload, without regard to the extent of renal dysfunction [11]. The strong correlation between N-BNP and CRP levels found in our study [9] suggests an association between increased left-ventricular filling pressure and inflammation in patients with CKD and we hypothesize that inflammation could be the consequence of an increased left-ventricular filling pressure. Indeed, we found that N-BNP was the unique independent factor affecting serum CRP level in multiple regression analysis. This concept could explain the non-normal distribution of CRP level among patients with chronic renal failure: only those patients with persistently high left-ventricular filling pressure (those with left-ventricular hypertrophy and left-ventricular systolic or diastolic dysfunction) may show persistently high levels of CRP.

The results of the study presented by Ates et al. [8] could support this concept, as they found a strong association between CRP values and LVMi and between CRP and fractional shortening. Probably, left-ventricular filling pressure and therefore BNP levels are higher in these patients with left-ventricular hypertrophy or left-ventricular dysfunction than in patients with normal echocardiographic parameters. The association between BNP and CRP levels could also explain the fluctuations over time in CRP values in the same patient. The changes in volume status, frequently detected in patients with CKD, could modify the left-ventricular filling pressure, BNP values and therefore CRP levels, due to the strong correlation between the two parameters. Indeed, some authors [12] have shown that extracellular water, measured by bioimpedance, was a powerful predictor of BNP levels in hemodialysis patients, suggesting that the increased synthesis of BNP in these patients appear to be mainly related to volume rather than to pressure stress.

In summary, Ates and colleagues conclude in their interesting manuscript that serum CRP is an independent factor affecting $\mathrm{CV}$ disease in patients with $\mathrm{CKD}$, based on a strong direct association between CRP values and echocardiographic data of left-ventricular hypertrophy or dysfunction. In my opinion, there could be, on the contrary, another explanation for these findings: inflammation could be the consequence, rather than the cause, of increased left-ventricular filling pressure, related to ventricular dysfunction, hypervolemia or both. If further studies support this concept, early intervention in patients with mild renal insufficiency in order to reduce leftventricular hypertrophy and, specially, a strict control of volume overload over time could reduce the prevalence of inflammation among patients with chronic kidney disease.

\section{References}

1 Muntner P, He H, Hamm L, Loria C, Whelton PK: Renal insufficiency and subsequent death resulting from cardiovascular disease in the United States. J Am Soc Nephrol 2002;13: 745-753.

2 Owen WF, Lowrie EG. C-reactive protein as an outcome predictor for maintenance hemodialysis patients. Kidney Int 1998;54:627636.

3 Zimmermann J, Herrlinger S, Pruy A, Metzger $\mathrm{T}$, Wanner C: Inflammation enhances cardiovascular risk and mortality in hemodialysis patients. Kidney Int 1999;55:648-658.

4 Yeun Y, Levine RA, Mantadilok V, Kaysen GA: C-reactive protein predicts all-cause and cardiovascular mortality in hemodialysis patients. Am J Kidney Dis 2000;35:469-476.

5 Stenvinkel P, Heimburger O, Paultre F, Diazfalusy U, Wang T, Berglund L, Jogestrand T: Strong association between malnutrition, inflammation and atherosclerosis in chronic renal failure. Kidney Int 1999;55: 1899-1911.
6 Ortega O, Rodriguez I, Gallar P, Carreño A Ortiz M, Espejo B, Jimenez J, Gutierrez M, Oliet A, Vigil A: Significance of high C-reactive protein levels in pre-dialysis patients. Nephrol Dial Transplant 2002;17:1105-1109.

7 Panichi V, Migliori M, De Prieto S, Taccola D, Bianchi AM, Giovannini L, Norpoth M, Metelli MR, Cristofani R, Bertelli AA, Sbregia G, Tetta C, Palla R, Colombo R: C-reactive protein and interleukin-6 levels are related to renal function in predialytic chronic renal failure. Nephron 2002;91:594-600.

8 Ateş K, Yilmaz Ö, Kutlay S, Ateş A, Nergizoğlu G, Ertürk Ş: Serum C-reactive protein level is associated with renal function and it affects echocardiographic cardiovascular disease in pre-dialysis patients. Nephron Clin Pract 2005;101:c190-c197.
9 Ortega O, Gallar P, Muñoz M, Rodriguez I, Carreño A, Ortiz M, Molina A, Oliet A, Vigil A: Association between C-reactive protein levels and $\mathrm{N}$-terminal pro-B -type natriuretic peptide in pre-dialysis patients. Nephron Clin Pract 2004;97:125-130.

10 Maeda K, Takatoshi T, Wada A, Hisnaga T, Kimoshita M: Plasma brain natriuretic peptide as a biochemical marker of high left ventricular end-diastolic pressure in patients with symptomatic left ventricular dysfunction Am Heart J 1998;135:825-832.

11 Takami Y, Horio T, Iwashima Y, Takiuchi S, Kamide K, Yoshihara F, NakamuraS, Nakahama $\mathrm{H}$, Inenaga $\mathrm{T}$, Kangawa $\mathrm{K}$, Kawano $\mathrm{Y}$ : Diagnostic and prognostic value of plasma brain natriuretic peptide in non-dialysis dependent CRF. Am J Kidney Dis 2004;44:420428.

12 Faglugli RM, Palumbo B, Ricciardi D, Pasini $\mathrm{P}$, Santirosi P, Vecchi L, Pasticci F, Palumbo $\mathrm{R}$ : Association between brain natriuretic peptide and extracellular water in hemodialysis patients. Nephron Clin Pract 2003;95:60-66. 